\title{
Female Economic Participation and Economic Growth: An Empirical Evaluation of the Nexus for sub-Saharan African Region
}

\author{
Olufunmilayo Olayemi Jemiluyi ${ }^{1}$ 8(D) $\triangle$ and Dauda Olalekan Yinusa ${ }^{2}$ 8 (D) \\ ${ }^{1}$ Department of Economics, Adeleke University, Ede, Nigeria \\ ${ }^{2}$ Department of Economics, Obafemi Awolowo University, Ile-Ife, Nigeria \\ $\triangle$ Corresponding Author: Olufunmilayo Olayemi Jemiluyi, E-mail: jemiluyi.olayemi@adelekeuniversity.edu.ng
}

\author{
ARTICLE INFORMATION \\ Received: December 08, 2020 \\ Accepted: February 14, 2021 \\ Volume: 3 \\ Issue: 1 \\ DOI: 10.32996/jefas.2021.3.1.7
}

\section{KEYWORDS}

Female Labour Force Participation, Economic Growth, sub-Saharan Africa, Female Economic Participation

\section{ABSTRACT}

More recently, there has been increasing recognition of gender perspective to achieve economic growth and sustainable development. Although the nexus between gender equality and economic growth has enjoyed sizeable consideration in the literature, empirical evaluation of the economic growth effect of female economic participation is few. Hence, this study seeks to examine the relationship between female economic participation and the economic growth process of the sub-Saharan African region. In particular, the study tests whether there is an economic growth premium due to female participation in economic activities using data for a sample of 35 sub-Saharan African economies. Employing the Prais-Winsten regression, the findings suggest the existence of a significant positive effect of female economic participation on economic growth in the region. Specifically, a per cent increase in female employment rate and female labour force participation leads to a 0.028 per cent and 0.021 per cent increase in economic growth. Also, the share of working population, domestic credit to the private sector and urbanization rate are positively correlated with economic growth during the study period. The findings imply that female economic empowerment is important for achieving economic growth in the region; hence empowerment of women and girls should be made focal in national and regional development plans as stipulated in goal 5 of the Sustainable Development Goals (SDG) plan.

\section{Introduction}

In recent times, the derivable externalities from gender inclusion across all walks of life - economic, social, and political - have drawn significant attention in policy and academic literature. In particular, the increasing recognition of gender roles in achieving economic growth and development has become topical and this is evidenced in the inclusion of gender-specific goals in the post-2015 Sustainable Development Goals (SDGs) ${ }^{2}$ as well as the increased focus of global development community and multilateral agencies on the issue of gender inequality (OECD, 2020, 2015; World Bank, 2012, 2018; IMF, 2013, 2016 ). Following the increasing wave of both theoretical and empirical analyses of gender roles in promoting economic growth and sustainable development, the inclusion of women in economic activities has been associated with poverty alleviation (Nadim \& Nurlukman, 2017; OECD Forum, 2015; Jones and Chant, 2009; World Bank, 2007) improved household welfare (Jabeen et al., 2020; Samer et al., 2017; Ojo and Wurani, 2013), improvement in child education and nutrition (Sidh \& Basu, 2011; Afridi, Mukhopadhyay and Sahoo, 2016), diversity in workforce (Verick, 2018; Ziman, 2013), decline in domestic violence (Lenze \& Klasen, 2016; Schuler, Lenzi, Nazneen and Bates, 2013; Mathus and Slavov, 2012) and economic and environmental sustainability.

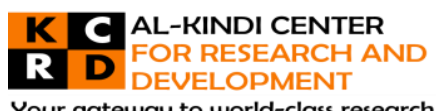

Your gateway to world-class research

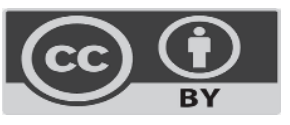

Published by Al-Kindi Center for Research and Development. Copyright (c) the author(s). This open access article is distributed under a Creative Commons Attribution (CC-BY) 4.0 license

\footnotetext{
${ }^{2}$ Goal 5 of the SDGs is to achieve gender equality and empower all women and girls. https://www.un.org/development/desa/disabilities/envision2030.html Examples of efforts of the global development community aimed at eradicating gender inequality include the United Nations Access Project for Girls and Women and the OECD Gender Initiatives. Also, gender equality is a core theme of the world bank i2i program
} 
Faced with the twin problems of poverty and gender inequality, gender economic inclusion is critical for Africa and the subregion of Saharan Africa. While the high growth witnessed in sub-Saharan Africa has minimally stemmed the tides of gender inequality over the last decades, gender inequality remains significantly high in the SSA region (OECD, 2019). Diverse socioeconomic and cultural factors have been adduced for women's low economic participation in the SSA region. Aside from the precarious challenge of jobless growth which has led to stiff competition for few or inexistent jobs, increase in spouse's income, low literacy level, the vulnerability of certain categories of job, safety concern, religion and cultural dictates have also been identified as significant predictors of low women's participation in the labor force or as an entrepreneur in SSA (Idowu and Owoeye, 2019; Atake and Gnakou, 2019; Chakravarty, Das and Vaillant, 2017; Adeyemi, Odusina and Akintoye, 2016; Batana and Gnakou, 2015)

Like most gender roles, economic inclusion ${ }^{3}$ is biased against women in SSA (World Development Indicator (WDI), 2019). This, in turn, has exacerbated gender inequality in the region. Although, globally there is a considerable gender gap in economic inclusion in favour of men, the statistics in SSA compare less favourably with other developing regions. (WDI, 2019). The statistics for female economic participation ${ }^{4}$ in most SSA countries are below the global averages, with about two-third of the women population engaged in agriculture and other low-income jobs (OECD/FAO, 2016; WDI, 2019). For example, while there has been significant change in the composition of female sectorial employment in SSA, with more women moving into the industrial and service sectors, the statistics still compares poorly with other developing regions.

In the decade between 1991 and 2000, the average percentage of women engaged in agriculture was $64.5 \%$ and fell to $54.8 \%$ in the period between 2011 and 2019, while in the same periods, it fell from 10.5 percent to 7.4 percent in Latin America and from 45.5 percent to 26 percent in East Asia region. Also, in the same period, the proportion of women employed in the service sector rose from 27.4 percent to 50.7 percent in SSA, while it increased from 73.9 percent to 80.4 percent in Latin America. The regional average for women's employment in SSA stood at 7.8 percent while it was 12.2 and 22.9 percent respectively in East Asia and Latin America. In the same vein, while in 2019 the proportion of women in wage and salaried employment was 64.03 percent and 64.7 percent respectively in Latin America and East Asia, it was as low as 17.6 percent in the SSA region. In spite of the lowincome characterizing the chunk of female employment, 81.09 percent of female employment in SSA was classified as vulnerable in 2019 compared with 46.7 percent and 33.3 percent in East Asia and the Latin America respectively (WDI, 2019).

Sequel to the poor statistics in terms of the quality and quantity of women economic inclusion in SSA, economic outcomes of women in particular and those of the overall economies are adversely affected (Chakravarty et al., 2017). Due to higher financial capacity and exposure at workplace, men get more trained than women through further studies and on-the-job-training, have better capacity to save and start business ventures, with adverse implications for workforce diversity, level of investment, output growth, and social and political inclusion. For example, according to the IMF Regional Economic Outlook (2016), gender inequality together with income inequality accounted for about one percent growth shortfall in SSA. Also, based on 2018 International Labor Organization (ILO) statistics, Brookings Institution showed that gender equality in the SSA labor market would have raised the number of active women in the labor force by over 40 million and the attendant increase in output growth would have ranged between 1 to 50 percent across the various economies (Brookings, 2018)

Consequent to the increasing recognition of gender roles in economic growth and sustainable development, both policy and empirical literature have been replete with the investigation of the nexuses between gender inclusion and various macroeconomic variables. ${ }^{5}$ However, a review of the growing strand of the literature reveals the paucity of empirical analyses of the economic growth effect of female economic inclusion in SSA. A sizeable number of country specific and panel studies in the extant literature have their focal attention in the investigation of the Goldin U-shaped hypothesis ${ }^{6}$. While such an analysis is considered important, it is not the focus of this study. This study contributes to the small but growing literature on female economic inclusion, taking clue from recent studies such as Asongu and Odhiambo (2018, 2019), Asongu, Efobi, Tanankem and Osabuohien (2019), Efobi, Tannkem and Asongu, 2018. While these studies investigated the nexuses between female economic participation and other macroeconomic variables such as ICT, financial access, and globalization in the SSA region, the current

\footnotetext{
${ }^{3}$ Economic inclusion is defined in the context of this study as the opening of economic opportunities for the female working share of the population.

${ }^{4}$ Measured in this study as female labor force participation rate and percentage of women (15 years + ) in employment. The terms "female economic participation", "female economic inclusion" and "gender inclusion" are used interchangeably throughout the study.

${ }^{5}$ See Gaddis and Klasen (2014) on women labor force participation and economic development and structural changes; Efobi, Tanankem and Asongu (2018) on female economic participation and advancement in information and communication technology (ICT), Hendrick (2019) on the role of financial inclusion in female economic empowerment, Asongu and Odhiambo (2018) on financial access and gender economic inclusion, Asongu, Efobi, Tanankem and Osabuohien, (2019) on globalization and female economic participation Jemiluyi and Alao-Owunna (2020) on female health and economic growth.

${ }^{6} \mathrm{~A}$ functional analysis of the relationship between female economic participation and level of economic development.
} 
study examines the role of female economic participation in the region's growth trajectory. Gender-specific disparities in terms of economic participation bear high economic cost not only for women but also for the economies as a whole as it lowers growth performance, thereby reducing overall welfare (Chakravarty et al. 2017; IMF, 2013; 2016). It may also restrict the talent population of a nation's labor force as less qualified men may push potential highly qualified women out of the job market, thereby endangering the economy's international competitiveness. An increase in female participation has been argued not only to increase the workforce size but also creates greater diversity of the work force potentials (IMF, 2013; OECD) Thus, an examination of the female economic participation-economic growth nexus is important for the SSA region characterized by the low growth rate, high burden of poverty and gender inequality.

\section{Literature review}

Since the seminal work of Boserup (1970) and Goldin (1994), examination of the roles of women in economic growth and development has enjoyed sizeable attention in the literature. The review of the extant literature can be couched into three major strands. First, a large chunk of the available evidence focused on the relationship between gender inequality in general and economic growth. Following from the conclusions of both country-specific and cross-country analyses in this category, there seems to be a near-consensus that gender inequality inhibits growth (Seguino, 2019; Hussein, 2019; Vasconez, 2018; Klasen, 2018; Gelard and Abdi, 2015, Goher, 2013) with the effects varying in magnitudes.

Another strand of the literature focuses on the investigation of the Goldin U-shaped female labor force function, otherwise known as the $\mathrm{U}$-shaped feminization hypothesis. Available evidence shows that divergent conclusions characterize this strand of the literature. While the $U$-shape hypothesis is corroborated in a large body of panel and time-series studies, evidence of the $U$ shape could not be affirmed in a sizeable number of studies. Disaggregating 28 European Union (EU) member countries into two samples of old and new members, Altuzarra et al. (2019) confirm the U-shaped female labor force function for the whole sample and 13 new-member samples not for the 15 old-members sample. The U-shaped feminization hypothesis has earlier been affirmed by Altarawneh (2018), Husain (2016), and Muhajid (2013) for Jordan, Bangladesh and Pakistan, respectively. It has also been corroborated in panel studies including Lechman and Kaur (2015), Olivetti (2013) and Tam (2011). Contrarily, the U-shaped hypothesis could not be affirmed by Idowu and Owoeye (2019) for a sample of African countries, Lahoti and Swaminathan (2016) for Indian states and Vermes (2015) for a panel of Middle East and North African countries. While these are in variance with the popular consensus in the literature, they corroborate the findings of similar studies such as Dogan and Akyuz (2015), Gaddis and Klasen (2014), which have documented an inverted U-shaped or no relationship between women labour force participation and economic growth.

In addition, another strand of the literature has also focused on the role of women in economic development by investigating the nexuses between women economic participation and various macroeconomic determinants of output growth such as financial access and inclusion (Hendrick, 2019; Asongu and Odhiambo, 2018), domestic saving (Floro and Seguino, 2002), entrepreneurial development (Balachandra and Dublish, 2019; Bastian, Metcalfe \& Zali, 2019; Udanoh and Zouria, 2018) and human capital development (Wodon and Onagoruwa, 2019; Goher, 2013)

Lastly, a tiny but growing strand of the literature focuses on the direct impact of female economic participation on economic growth. The strand is similarly characterized with inconclusive findings. Testing the effect of female participation in the labor market of 21 African countries, Obodoechine (2019) finds that increased female participation significantly raises average output during the period of study. Also, the pro-growth effect of female participation in the economy has earlier been substantiated in $\mathrm{Na-Chiengmai} \mathrm{(2018).} \mathrm{Estimating} \mathrm{panel} \mathrm{autoregressive} \mathrm{distributed} \mathrm{lag} \mathrm{(ARDL)} \mathrm{model} \mathrm{for} 122$ countries, the study affirms that increasing female participation in economic activities is a significant predictor of economic growth. Similarly, the economic growth advantage of female economic inclusion is corroborated by Tsani et al. (2013) for South Mediterranean countries within a general equilibrium framework. In particular, the study finds that lowering the barriers to female labor force participation serves as a catalyst to economic growth in the region. Furthermore, forecasting the effect of an increase in female labor force participation on economic growth trajectories of the OECD member countries, Thevenon et al. (2012) affirm that raising the rate of women participation in the labor force significantly stimulates economic growth.

However, in a contrary opinion, Adofu and Okwanya (2018) find that female participation in the economy is negatively related to the economic growth trajectory of Nigeria. Also, evaluating the nexus in Cameroon Forgha and Mbella (2016) find that female labor force participation retard growth based on the estimates of a generalized method of moment (GMM) model. And using the Arellano and Bond dynamic panel model, Denghani and Firouzjai (2015) similarly find that female labor force participation is negatively correlated with economic growth in the Organization of Islamic Countries (OIC).

\section{Methodology \\ 3.1 Technique of analysis}

Page | 74 
To evaluate the relationship between female economic inclusion and the economic growth process of SSA, the adopted econometric methodology is the panel data analysis. Based on findings from extant literature, panel models have been adjudged efficient with inherent advantages of controlling for heterogeneity, mitigating the effect of multi-collinearity and improving the efficiency of estimation techniques relative to time series models (Baltagi, 2005). For the estimation of panel data models, the literature is replete with various estimators, the commonest being the ordinary least square estimators such as pooled OLS, random and fixed effect estimators. However, the biasedness and inefficiency of the ordinary least square (OLS) estimator in the presence of serial dependence in the error terms is no longer a novel issue in econometric analysis. Autocorrelation of the error terms and violation of other assumptions of OLS adversely affect the optimality of the OLS estimator, thereby yielding unreliable estimates with the attendant consequence of misleading policy inferences (Lee and Lund, 2004; Anderson, 1954).

In an attempt to correct the problem of autocorrelation in linear regressions, several approaches have been suggested in the literature. A classic example of the approaches is the Prais-Winsten (1954) model using the least square estimator. The PraisWinsten estimator is a generalized least squares (GLS) estimator which corrects for the first-order autocorrelation in the transformed GLS model. The estimator is an improvement over the Cochrane-Orcutt (1949) estimator unlike the latter. It makes use of the first observation of the transformed data. Prais and Winsten, in their seminal contribution to the efficiency of OLS estimates, rather than using the lag definition and loses the level information in the first observation as in Cochrane-Orcutt estimator, separately transform and make use of the first observation. This, in particular, has been a significant advantage of the Prais-Winsten estimator over other GLS estimators in small samples. Furthermore, the efficiency and robustness of the PraisWinsten regression have been well documented in the literature, adjudging it to be more efficient when the order of autocorrelation is not known a priori and when the variance of the initial error term tends to infinity (Dielman and Rose, 1994; Thornton, 1987)

Thus, for the evaluation of the relationship between female economic inclusion and economic growth trajectory in SSA region, this study adopts the Prais-Winsten estimator sequel to the violation of the homoscedasticity and autocorrelation assumption of the estimated OLS model ${ }^{7}$

\subsection{Data and empirical model}

For the empirical analysis of this study, the OLS model below is estimated

$y_{i t=} \alpha_{i t}+\beta X_{i t}+e_{i t}$

where $X$ represents a vector of measures of female economic inclusion, $\alpha$ and e represent the constant term and the error term, respectively. $\beta$ is the measure of change in economic growth with respect to female economic inclusion, and subscript $t$ and $i$ respectively denote the period and member countries that make up the panel of SSA countries. In particular, the vector $X$ comprises of female labor force participation and female employment rate, which have been well adopted in the extant literature as important measures of female economic inclusion (Asongu and Odhiambo, 2019; Efobi et al., 2018). Moreover, to avoid the problem of model misspecification, we include control variables other macroeconomic aggregates that have been identified as important predictors of economic growth. Specifically, data on foreign direct investment, the proportion of the working-age population (15-64 years) as a percentage of total population (WPOP), domestic credit to the private sector as a measure of financial development and degree of urbanization were collected. Thus, equation (1) is transformed as follows to account for the alternation of the independent variables and inclusion of the control variables.;

$y_{i t=} \alpha_{i t}+\eta_{1} F E I_{i t}+\eta_{2} F D I_{i t}+\eta_{3} W P O P_{i t}+\eta_{4} D C P S_{i t}+\eta_{5} U R B_{i t}+e_{i t}$

For the avoidance of the problem of autocorrelation which may arise from simultaneous inclusion of both measures of female economic participation, we estimate two different models to investigate the effect of female inclusion in the economy in SSA. Also, this will permit for the assessment of the relative effectiveness of each measure in the growth trajectories. Specifically, this will help in the discovery of which of female economic participation rate and female employment rate is more important for economic growth in the region.

For the empirical assessment of the objective of the study, a panel dataset for the period 2004-2018 is created using time series data of thirty-five SSA countries. This represents about 73 percent of the forty-eight SSA member countries. The source of the data employed in this study is the online database of the World Bank - World Development Indicators (WDI). While the choice of countries is largely determined by data availability, the choices were carefully made to ensure that the selected sample well

\footnotetext{
${ }^{7}$ Prior to estimating the Prais-Winsten regression, we estimated an OLS model and tested same for heteroscedasticity and autocorrelation.
} 
represents the sub-region ${ }^{8}$. Table 1 presents the definition of the variables employed in this study. The table portrays the adopted codes for the variables and the unit of measurement of each variable.

Table 1: Definitions of the adopted variables

\begin{tabular}{|l|l|l|}
\hline Variables & Definitions & Units of measurement \\
\hline GDPG & GDP growth rate & Percent \\
\hline FEMP & Female employment to population ratio & Percent \\
\hline FLFP & Female labor force participation rate & Percent \\
\hline FDI & Foreign direct investment net inflows & US\$ \\
\hline WPOP & Population 15-64 years (\% of total population) & Percent \\
\hline DCPS & Domestic credit to private sector & Percent \\
\hline URB & Urbanization rate & Percent \\
\hline
\end{tabular}

Author's computation based on data from World Development Indicators (2019)

\section{Results and discussions: Prais-Winsten regression estimates}

This section focuses on the presentation of the econometric results as well as the discussion of the findings. The results of the PW regression are displayed in Table 2. The results show the coefficients, direction and significance of the effects of the independent variables on economic growth in SSA. As earlier indicated, the FEI measures are alternated in equation (2) and the results for the FEMP and FLFP models are presented in column II and II, respectively. The reported coefficients for female economic inclusion measures show an economic growth premium due to female participation in the economy as both female employment rate and female labor force participation rate are positively related to economic growth during the study period. Quantitatively, a percentage increase in female employment rate is related to about 0.03 percent increase in the rate of growth of the economy and the estimate is statistically distinguishable from zero at one percent level of significance. Similarly, the estimated coefficient for FLFP shows that the rate of female participation in the labor force is growth-inducing with a percentage increase in FLFP causing 0.02 percent increase in economic growth. However, the estimate is only statistically different from zero at 10 percent level of significance.

The obtained results for the two measures of FEl is in consonance with studies that have documented the pro-growth effect of female economic participation as well as those which have established that bridging the gender gap in labor force participation and employment is growth-enhancing (Seguino, (2019; Hussein, 2019; Vasconez, 2018; Klasen, 2018; and IMF, 2016). The findings, in particular, corroborate the Brookings Institutions (2018) stance that increased female inclusion in productive sectors would exert a significant impact on the growth and development of sub-Saharan African economies. While the pro-growth effect of female economic inclusion could be hinged on diverse factors, female entrepreneurial development in SSA region has been conspicuous in the literature. In recent time, female entrepreneurial roles in SSA have risen remarkably higher relative to other sub-regions of the Africa continent as well as other regions of the world, making significant contributions in the area of job creation, income generation and serving as a critical tool of inequality reduction in the region (Global Entrepreneurship Monitor (GEM), 2019),

For the relative effectiveness of both measures of $\mathrm{FEI}$, the estimated coefficients show that the female employment rate marginally drives economic growth more than the female labor force participation rate in SSA. This is quite expected in that the female employment rate indicates the actual proportion of the female population (age 15 above) that is engaged in any activity to produce goods or services for pay or profit, while female labor participation rate is the proportion of the female working population (age 15 years above) who supply labor for the production of goods and services during a specified period of time (WDI, 2019)

Table 2: Summary of the Prais-Winsten (PW) regressions

Dependent variable: GDP growth rate (GDPG)

\begin{tabular}{|c|c|c|}
\hline Variables & Model 1 & Model II \\
\hline
\end{tabular}

\footnotetext{
${ }^{8}$ The selected countries include Angola, Benin, Botswana, Burkina Faso, Burundi, Cabo-Verde, Cameroon, Ghana, Guinea, Guinea-Bissau, Kenya, Lesotho, Madagascar, Malawi, Mali, Mauritania, Mauritius, Mozambique, Namibia, Niger, Nigeria, Rwanda, Sierra Leone, South Africa, Tanzania, Togo, Uganda, Zambia
} 


\begin{tabular}{|l|c|c|}
\hline & & - \\
\hline Female employment (FEMP) & $0.028^{*}$ & $(0.011)$ \\
\hline Female labor force participation rate (FLFP) & - & $0.021^{* * *}$ \\
& & $0.011)$ \\
\hline Foreign direct investment (FDI) & $-0.017^{* * *}$ & $-0.052^{* *}$ \\
& $(0.028)$ & $(0.027)$ \\
\hline Working Population (POPW) & 0.059 & 0.054 \\
& $(0.101)$ & $(0.101)$ \\
\hline Domestic credit to private sector (DCPS) & $0.538^{*}$ & $0.535^{*}$ \\
& $(0.036)$ & $(0.036)$ \\
\hline Urbanization (URB) & $0.252^{* *}$ & $0.292^{* *}$ \\
& $(0.112)$ & $(0.121)$ \\
\hline Constant & -5.372 & -5.565 \\
& $(3.892)$ & $(3.731)$ \\
\hline$R-$ squared & 0.368 & 0.364 \\
Wald $\chi^{2}$ & 443.7 & 414.6 \\
Prob $>\chi^{2}$ & 0.000 & 0.000 \\
\hline
\end{tabular}

The panel-corrected standard errors (PCSE) are included in brackets

* denotes statistical significance at 1 percent level

** denotes statistical significance at 5 percent level

*** denotes statistical significance at 10 percent level

As indicated in Table 2, the obtained coefficients for the control variables are close in magnitudes in the estimated models. In both models, foreign direct investment is negatively related to economic growth; and in both instances, the null hypothesis that the estimated coefficients are not different from zero is rejected at 10 and 5 percent level of significance, respectively. While these findings are contrary to the popular consensus that foreign investment is pro-growth, similar findings were documented by Anetor, Esho and Nsiah (2020) and Carbonell and Werner (2018) for the Spain panel sub-Saharan African countries, respectively. However, none of the models is the estimated positive effect of the working population statistically distinguishable from zero.

Furthermore, urbanization and banks' lending in the form of domestic credit to the private sector significantly positively affect economic growth in sub-Saharan Africa during the study period. The magnitudes of the effects are large and statistically distinguishable from zero in both models. Globally, urbanization has been linked to economic transformation and growth. In particular, in sub-Saharan Africa, aside from the structural transformation of the economies towards productive sectors, urbanization has similarly reshaped the sectoral composition of the economies with tangible growth in sectorial GDP (Arouri et al., 2014). In the same vein, the catalytic role of financial development in the growth of the African economies has been widely documented (Akinlo, 2020; Ibrahim and Alagidede, 2018). Regulated credit growth based on sound credit policy stimulates economic growth through the investment channel.

\section{Conclusion}

This paper has added to the existing evidence on the nexus between female economic participation and economic growth. In particular, we explored the relationship using two measures of female economic inclusion popularized in the literature, namely female employment rate and female labor force participation rate. The study focuses on 35 sub-Saharan African countries and the analysis spans through the 2004-2018. Employing the Prais-Winsten OLS regression, the results suggest that an increase in women's economic inclusion impacts positively the economic growth trajectory of the SSA region. Thus, female economic inclusion is pivotal to economic growth in SSA countries. Therefore, an important policy implication emerges that governments of the sampled economies should prioritize gender equality to enhance economic growth in the region. Governments of the SSA economies should formulate and implement policies that will catalyze the speed of progress on achieving goal 5 of SDG, to achieve gender equality and empower all women and girls by 2030. In particular, female economic empowerment should be made focal in national and regional economic plans.

Funding: This research was funded by African Economic Research Consortium (AERC) , grant number TT19005" . Conflicts of Interest: The authors declare no conflict of interest. 


\section{Reference}

[1] Adeyemi, O., Odusina, K., \& Akintoye, A. (2016). Religion and labour force participation in Nigeria: is there any inequality among women. African Journal of Reproductive Health, 20(3), 75-84.

[2] Adofu, I., \& Okwanya, I. (2018). Female labour force participation and economic growth in Nigeria. Ilorin Journal of Economic Policy, Department of Economics, University of Ilorin, 5(5), 1-11

[3] Afridi, F., Mukhopadhyay, A. and Sahoo, S. (2016). Female labor force participation and child education in India: evidence from the National Rural Employment Guarantee Scheme. IZA Journal of Labor Development 5(7). https://doi.org/10.1186/s40175-016-0053-y

[4] Altarawneh, Y. (2018). Economic development and female labour force participation in Jordan: a test of the u-shaped hypothesis. Jordan Journal of Economic Sciences,

[5] Altuzarra, A., Galvez-Galvez, C., \& Gonzalez-Flores, A. (2019). Economic development and female labour force participation: the case of European Union countries. Sustainability, 11,1962. https://doi.org/10.3390/su11071962

[6] Anderson, R. (1954). The problem of autocorrelation in regression analysis. Journal of the American Statistical Association, 49(265), 113-129.

[7] Anetor, F., Esho, E., \& Nsiah, C. (2020). The impact of foreign direct investment, foreign aid and trade on poverty reduction: evidence from sub-Saharan African countries. Cogent Economics and Finance, 8(1), 1737347. https://doi.org/10.1080/23322039.2020.1737347

[8] Arouri, M., Youssef, A., Nguyen-Viet, C., \& Soucat, A. (2014). Effects of urbanization on economic growth and human capital development in Africa. Program of Global Demography of Aging at Harvard University Working Paper No. 119.

[9] Asongu, S., \& Odhiambo (2018). ICT, financial access and gender inclusion in the formal economic sector: Evidence from Africa. The African Finance Journal, Africagrowth Institute, 20(2), 45-65.

[10] Asongu, S., \& Odhiambo, N. (2019). Inequality and the economic participation of women in sub-Saharan Africa: An empirical investigation. African Journal of Economic and Management Studies, 11(2), 193-206. https://doi.org/10.1108/AJEMS-01-2019-0016

[11] Asongu, S., Efobi, U., Tanankem, B., \& Osabuohien, E. (2019). Globalization and female economic participation in sub-Saharan Africa. Gender Issues. https://doi.org/10.1007/s12147-019-09233-3

[12] Atake, E., \& Gnakou, P., (2019). Women's empowerment and fertility preference in high fertility countries in sub-Saharan Africa. BMC Women's Health, 19, 54. https://doi,org./10.1186/s12905-019-0747-9

[13] Balachandra, L., \& Dublish, P. (2019). Women for women in entrepreneurship: understanding the role of other women for women's entrepreneurship. Crittenden, V. L. (Ed.) Go-to-market strategies for women entrepreneurs, Emeralds Publishing Limited, page $239-260$. https://doi.org.10.1108/978-1-78973-289-420191029

[14] Bastian, B., Metcalfe, B., \& Zali, M. (2019). Entrepreneurship in the MENA region. Sustainability, 29, 11. https://doi.org/10.3390/su11226472

[15] Batana, Y., \& Gnakou, P. (2015). An analysis of married women's empowerment in sub-Saharan Africa. African Economic Research Consortium (AERC) Research Paper No. 292. https://10.13140/RG.2.2.20590.10568

[16] Bennett, L. (1988). The role of women in income production and intra-household allocation of resources as a determinant of child nutrition and health. Food and Nutrition Bulletin, 10(3).

[17] Boserup, E. (1970). Women's role in economic development. Earthscan.

[18] Brookings Institution (2018). Closing the gender gap in African labour market is good economics. Retrieved from: https://www.brookings.edu/blog/africa-in-focus/2020/01/23/closing-the-gender-gap-in-african-labor-markets-is-good-economics/

[19] Carbonell, J., \& Werner, R. (2018). Does foreign direct investment generate economic growth? A new empirical approach applied to Spain. Economic Geography, 94(4), 425-456. https://doi.org/10.1080/00130095.2017.1393312

[20] Chakravarty, S., Das, S., \& Vaillant, J. (2017). Gender and youth employment in sub-Saharan Africa: a review of constraints and effective interventions. World Bank Research Paper No. 8245.

http://documents1.worldbank.org/curated/en/725431511188618886/pdf/WPS8245.pdf

[21] Canjels, E., \& Watson, M. (1994). Estimating deterministic trends in the presence of serially correlated errors. Federal Reserve Bank of Chicago Working Paper Series (WP 94-19).

[22] Desilet, L. (2019). Exploring the impacts of women's economic empowerment initiatives on domestic violence. A summary report for Oxfam's knowledge hub on violence against women and girls and gender-based violence. Available:

https://oxfamilibrary.openrepository.com/bitstream/handle/10546/620867/rr-womens-economic-empowement-domestic-violence120919-en.pdf;jsessionid=844FBDD4EB895C7A3BA96142F22CB95D?sequence=2 (July 19. 2020)

[23] Dielman, T., \& Rose, E. (1994). Estimation in least absolute value regression with autocorrelated errors. Journal of Statistical and Computational Simulation, 50, 29-43.

[24] Efobi, U., Tanankem, B., \& Asongu, S. (2018). Female economic participation with information and communication technology advancement: Evidence from sun-Saharan Africa. South African Journal of Economics, 86(2). https://doi,org/10.1111/saje.12194

[25] Floro, M., \& Seguino, S. (2002). Gender effects on aggregate saving. World Bank Policy Research Report on Gender and Development Working Paper Series No. 23. Available: http://documents1.worldbank.org/curated/en/831241468137395704/pdf/341660Gender0wp23.pdf (July, 19. 2020)

[26] Gaddis, I., \& Klasen, S. (2014). Economic development, structural change, and women's labour frce participation: a reexamination of the feminization U hypothesis. Journal of Population Economics, 27(3), 639-681. https://doi.org/10.1007/s00148-013-0488-2

[27] Gelard, P., \& Abdi, A. (2015). Evaluating the effect of gender inequality on economic growth in countries with high human development index. European online Journal of Natural and Social Sciences: Proceedings, 4(1)

[28] Global Entrepreneurship Monitor (GEM) (2019). 2018/2019 Entrepreneurship Report. Available: https://www.babson.edu/media/babson/assets/blank-center/GEM-2018-2019-Women's-Report.pdf (May, 20, 2020)

[29] Goher, F. (2013). Gender inequality in human capital accumulation and economic growth: a comparative analysis of Pakistan and Sri Lanka. Asia Pacific Journal of Social Work and Development, 23(4), 242-252. https://doi.org/10.1080/02185385.2013.778786

[30] Goldin, C. (1995). The U-shaped female labour force function in economic development in economic history in: Schultz, T. P. (Ed.). (1995). Investment in women's human capital, University of Chicago Press. 
[31] Hendrick, S. (2019). The role of financial inclusion in women's economic. Development in Practice, 29(8), 1029-1038. https://doi.org/10.1080/09614524.2019.1660308

[32] Husain, H. (2016). Economic development, women empowerment and U- shaped labour force function: time series evidence for Bangladesh. Asian Economic and Financial Review, 6(12): 719-728. https://doi.org/10.18488/journal.aefr/2016.6.12/102.12.719.728

[33] Hussein, H., (2019). Gender inequality and economic growth: a methodological divide. SageSubmissions. Preprint. https://doi.org/10.31124/advance.9918194.v1

[34] Ibrahim, M, \& Alagidede, P. (2018). Effect of financial development on economic growth in sub-Saharan Africa. Journal of Policy Modelling, 40(6), 1104-1125. https://doi.org/10.1016/j.polmod.08.001

[35] Idowu, O., \& Owoeye T. (2019). The supply of female labour force participation in selected African countries. Business and Social Science Journal, 4(1), 14-30.

[36] Idowu, O., and Owoeye T. (2019). Female labour force participation in sub-Saharan African countries: an empirical analysis. Indian Journal of Human Development, 13(3), 278-293. https://doi.org/10.1177/0973703019895234.

[37] International Monetary Fund (IMF) (2013). Women, Work, and the Economy: Macroeconomic

[38] Gains from Gender Equity. IMF Staff Discussion Paper SDN/13/10.

[39] International Monetary Fund (2016). Inequality, gender gaps and economic growth: comparative evidence for sub-Saharan Africa. IMF Staff Working Papers WP/16/111

[40] Jabeen, S., Haq, S., Jameel, A., Hussain, A., Asif, M., Hwang, J., \& Jabeen, A. (2020). Impacts of Rural Women's Traditional Economic Activities on Household Economy: Changing Economic Contributions through Empowered Women in Rural Pakistan. Sustainability, $12,2731$. http://dx.doi.org/10.3390/su12072731

[41] Jemiluyi, O. O., and Alao-Owunna, I. (2020). A reconsideration of the health status-economic growth nexus: Evaluation of the gender differential effect in Nigeria. Eurasian Journal of Economics and Finance, 8(4), 217-230.

[42] Jones, G., \& Chant, S. (2009). Globalizing initiatives for gender equality and poverty reduction: exploring 'failure' with reference to education and work among urban youth in The Gambia and Ghana. Geoforum, 40(2), 184-196. https://doi.org/10.1016/j.geoforum.2008.07.008

[43] Kim, J., Lee, J. W., \& Shin, K. (2018). Gender Equality and Economic Growth in Korea. Pacific Economic Review, doi: http://dx.doi.org/10.1111/1468-0106.121812016

[44] Klasen, S. (2018). The impact of gender inequality on economic performance in developing countries. Annual Review of Resource Economics, 10, 279-298. https://doi.org/10.1146/annurev-resource-100517-023429

[45] Lee, J., \& Lund, R. (2004). Revisiting simple linear regression with autocorrelated errors. Biometrika, 91(1), $240-245$.

[46] Lahoti, R., \& Swaminathan, H. (2016). Economic development and women's labour force participation in India. Feminist Economics, 22(2), 168-195. https://doi,org/10.1080/13545701.2015.1066022.

[47] Lechman, E., \& Kaur, H. (2015). Economic growth and female labour force participation - verifying the U-feminization hypothesis. New evidence for 162 countries over the period 1990-2012. Economics and Sociology, 8(1), 246-257. https://doi.org/10.14254/2071789X.2015/8-1/19

[48] Lenze, J., \& Klasen, S. (2016). Does women labour force participation reduce domestic violence? Evidence from Jordan. Feminist Economics, 23(1), 1-29. https://doi.org/10.1080/13545701.2016.1211305

[49] Muhajid, S., Muhammed, S., and Noman, M. (2013). Economic growth-women labour force participation nexus: an empirical evidence for Pakistan. Developing Countries Studies, 3(3).

[50] Nadim, S., \& Nurlukman, A. (2017). The impact of women empowerment on poverty reduction in rural area of Bangladesh: focusing on villages development program. International Journal of Technology and Globalization, 9(7).

[51] Olivetti, C. (2013). The female labor force and long-run development: the American experience in comparative perspective. NBER working paper 19131.

[52] Na-Chiengmai, D. (2018). Female labour force contribution to economic growth. Chiang Mai University Journal of Economics, 22(3), 47-62.

[53] Obodoechine, E.N. (2019). Impact of Female Labor Participation in African Countries. University Honors Program Theses. 432. https://digitalcommons.georgiasouthern.edu/honors-theses/432

[54] OECD (2008). Gender and Sustainable Development: Maximizing the Economic, Social and

[55] Environmental Role of Women. Available: https://www.oecd.org/social/40881538.pdf, (June 10, 2020)

[56] OECD (2015). Gender equality: why a push for gender equality makes a sound economic sense. Available: http://www.oecd.org/gender/push-gender-equality-economic-sense.htm (July 19, 2020)

[57] OECD (2019). Sub-Saharan Africa: the social institutions and gender index (SIGI) regional report. Available: https://www.oecd.org/dev/development-gender/Mini-Brochure_SIGI_AfriqueSubsaharienne_EN-web.pdf (May 7, 2020)

[58] OECD (2020). COVID-19: time for gender inclusive decision- making. Available: http://www.oecd.org/gender/push-gender-equalityeconomic-sense.htm (July 19, 2020)

[59] Ojo, C., \& Wurani, B. (2013). Analysis of the Extent of Women's Contribution to Household Welfare. Journal of Social Sciences, COES\&RJ-JSS, 2(2), 101-107. Available at SSRN: https://ssrn.com/abstract=2246410

[60] Prais, S., \& Winsten, C. (1954). Trends estimators and serial correlation. Cowles Foundation Discussion Paper 383.

[61] Samer, S., Al-Shami, A., Majid, I., Mohmad, R., \& Rashis, N. (2017). Household welfare and women empowerment through microcredit financing: evidence from Malaysia microcredit. Journal of Human Behaviour in the Social Environment, 27(8), 894-910. https://doi.org/10.1080/10911359.2017.1345341

[62] Schuler, S., Lenzi, R., Nazneen, S., \& Bates, L. (2013). Is women's empowerment contributing to a decline in intimate partner violence against women in Bangladesh? Evidence from a qualitative study. Study of Family Planning, 44(3). https://doi.org/10.1111/j.17284465.2013.00356.x

[63] Seguino, S. (2019). Engendering macroeconomic theory and policy. Feminist Economics, 26(2), 27-61. https://doi.org/10.1080/13545701.2019.1609691 
[64] Sidh, S., \& Basu, S. (2011). Women's Contribution to Household Food and Economic Security: A Study in the Garhwal Himalayas, India. Mountain Research and Development, 31(2), 102-111. http://dx. 102 doi.org/10.1659/MRD-JOURNAL-D-10-00010.1

[65] Tam, H. (2011). U-shaped female labour participation with economic development: some panel data evidence. Economic Letters, 110 (2011), 140-142. https://doi.org/10.1016/j.econlet.2020.11.008

[66] Thevenon, O. (2013). Drivers of female labour force participation in the OECD. OECD Social, Employment and Migration Working Papers, No. 145, OECD Publishing. http://dx.doi.org/10.1787/5k46cvrgnms6-en

[67] Thornton, D. (1987). A note on the efficiency of the Cochrane-Orcutt estimator of the AR(1) regression model. Journal of Econometrics, 36(3), 369-376. https://doi.org/10.1016/0304-4076(87)90008-X

[68] Udanoh, M., \& Zouria, A. (2018). Using gender inequality to predict the rate of African women entrepreneurship. International Journal of Emerging Trends in Social Sciences, 3(1), 17-28.

[69] Vasconez, R. (2018). Economic growth and gender inequality: an analysis of panel data of five Latin American countries. CEPAL Review, 2017/122. https://doi.org/10.18356/73d01ed-en

[70] Verick, S. (2018). Female labor force participation and development. IZA World of Labor, 2018: 87. https://doi.org/10.15185/izawol.87.v2

[71] Verme, P. (2015). Economic development and female labour participation in the Middle East and North Africa: a test of the U-shape hypothesis. IZA Journal of Labor and Development, 4(3). https://doi.org/10.1186/s40175-014-0025-z

[72] Wodon, Q., \& Onagoruwa, A. (2019). Gender inequality, human capital wealth and development outcomes in Uganda. The cost of gender inequality. World Bank, Washington, D.C. https://opemknowledge.worldbank.org/handle/10986/32787 License: CC BY 3.0 IGO

[73] World Bank (2007). Gender equality, poverty and economic growth. Policy research working paper, WPS 4349

[74] World Bank (2012). Gender equality for development. Available: https://www.worldbank.org/en/research/dime/brief/dime-gender-program (May 20, 2020)

[75] World Bank (2018). The world bank in gender. Available:: https://www.worldbank.org/en/topic/gender/ (May 20, 2020)

[76] Ziman, R. (2013). Women in the Workforce: An In-Depth Analysis of Gender Roles and Compensation Inequity in the Modern Workplace. Honors Theses and Capstones. 157. https://scholars.unh.edu/honors/157 